\title{
Gender disparity in work-family balance in academia: a study in the Sri Lankan university context
}

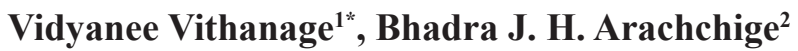 \\ ${ }^{l}$ Department of Human Resources Management, Faculty of Management and Finance, University of Ruhuna, Matara, Sri Lanka. \\ ${ }^{2}$ Department of Human Resource Management, Faculty of Management Studies and Commerce, University of Sri Jayewardenepura, Gangodawila, \\ Nugegoda, Sri Lanka.
}

\begin{abstract}
This article attempts to analyse the work-family balance of male and female academics in Sri Lankan universities, in view of the dearth of research on the gendered nature of work-family balance in academia. This study examines gender differences in work-family balance in academia. With the purpose of accomplishing the aforesaid objective, a survey was conducted with 63 male and 63 female university academics of Management Faculties in the University of Sri Jayewardenepura, University of Colombo, University of Kelaniya and University of Ruhuna. The sample was selected based on the cluster sampling technique. Further, the workfamily balance was measured along three dimensions, namely, time balance, involvement balance and satisfaction balance. An independent sample t-test was used for the purpose of data analysis. The results show that there is a significant difference in time balance, involvement balance and work-family balance between male and female academics. However, there is no statistically significant difference in satisfaction balance between male and female academics of the selected sample. Especially, social support may create a balance between work and family life for women academics in Sri Lanka.
\end{abstract}

Keywords: Involvement balance, satisfaction balance, time balance, work-family balance.

\section{INTRODUCTION}

The concept of work-family balance emerged during the 1980 s 'with a steep increase' of married women's entrance to the labor market (Barnett, 1999: p. 144). Accordingly,

"a gendered division of labor, with the wife caring for the family and the husband assuming the breadwinner role, was no longer a viable option for many couples" (Higgins et al., 1994: p. 144).

Therefore, most families have become dual earners (Haddock et al., 2006). It shows that "the ways mothers and fathers provide for and nurture their children have evolved" (Hill et al., 2003: p. 221). It is a consequence of ever-changing workforce demographics that have emerged with the industrial revolution. Though it improves the standard of living, this 'dual-earner' concept leads towards a conflict between work and family domains. Moreover, a comparative difference exists at present than past among both male and female, who have excessive involvement in higher education and are engaged in not just jobs but in careers as professional parents (Hill et al., 2003). On one hand, this would help to eradicate the gender discrimination. On the other hand, it may jeopardize the work and family life of male and female workers while reducing their time and energy for both roles.

According to the Department of Census and Statistics of Sri Lanka, women's participation in the employment in 2016 (the fourth quarter) was $36 \%$ and this shows an increase of $3.1 \%$ in comparison to 2012. Further, as per the occupation group statistics, executive grade employees of the year 2012 and the 2016 fourth quarter were $4.31 \%$ and $5.96 \%$, respectively. Because of the dual-earner concept, both males and females have to struggle with their time to find a balance between work life and family life. Most countries in the world have implemented several alternative work schedules to

*Corresponding author (vidyanee@gmail.com; (iD https://orcid.org/0000-0003-1006-2507) 
achieve work and family balance among their workers. Flextime, compressed workweeks and part-time employment are some of the examples of alternative arrangements of work. However, this kind of actions are yet to be implemented in Sri Lanka as the managers (both in the public and the private sectors) are not giving much consideration to work-family balance issues (Arachchige, 2013).

Academics' culture is mainly developed within a masculine framework (Gatta \& Roos, 2004). As far as academia is concerned,

"women are treated as occupying the private, domestic sphere, while men are seen as existing in the public, work sphere" (Gatta \& Roos, 2004: p.142).

Thus, these individuals face a lot of work-family imbalances caused by the conflict between work obligations and family obligations. According to Lawton \& Tulkin (2010), the behaviour of males and females in academia presents a contradiction when they achieve their tenure. As stated by them most female academics tend to live as single or if they are married, they try to postpone pregnancy. However, most male academics tend to marry and have children. The reason behind this is that men receive great support from their wives and children. Consequently, male academics reach higher positions without much difficulty, when compared to female academics. Due to the masculine framework of academia, female academics often work with male academics, though both have academic freedom, a mere illusion for many female academics (Gatta \& Roos, 2004; Acker \& Armenti, 2004). As far as university academics are concerned, many female faculty members typically demonstrate lower levels of research publications compared to male academics (Boshoff \& Bosch, 2012). Further, they have argued that, usually, male domination exists in research publications.

Previous studies in the West (Ward \& Wendel, 2004; Van der Lippe et al., 2006; Rafnsdottir \& Heijstra, 2011) indicate that there is a difference between male and female academics in balancing work and family. İn particular, Wickramasinghe \& Jayathilake (2006) have mentioned that women in Sri Lanka face huge challenges due to the traditional gender stereotypes embedded in Sri Lankan communities. More specifically, Sri Lankan culture has gradually moved away from male domination prevalent in the culture of most South Asian countries. Kailasapathy et al. (2014) noted that male spouses' traditional gender role orientation negatively influences the work-family balance of Sri Lankan women with a career. Conversely, Opatha \& Perera (2017) have found no significant difference between male and female accounting professionals regarding work-family balance. Such findings are inconsistent and inconclusive. Further, there was a dearth of research that addresses the workfamily balance of Sri Lankan male and female university academics who were experts in their fields of work. Accordingly, there is an issue of how the work-family balance varies among male and female academics in Sri Lanka. Thus, the purpose of this study is to examine how work-family balance varies among male and female academics in state universities of Sri Lanka.

The remainder of this paper is organised as follows: the relevant literature on gender and work-family balance will be reviewed, followed by a description of the research methods, a report of the study's findings, and a discussion of the findings. Subsequently, the implications will be presented and suggestions for future research will conclude the paper.

\section{LITERATURE REVIEW}

\section{Gender role}

\section{Gender is,}

"a constructive element of social relationships based on perceived differences between the sexes and a primary way of signifying relationships of power" (Scott, 1986: p. 1067).

According to Barnett (1999: p. 145), the general agreement of the community towards gender was that the "women's primary roles were as as wife and mother whereas men's primary roles were breadwinners". Further, Moen et al. (1995) argued that in every stage of life, women are influenced by expectations of others such as husband, children, aging parents and the community.

However, more than ever before, female workers are increasingly appearing in each and every field of work. As stated by Guest (2002: p. 257) "Women's entrance to the labor market has evolved with the social and economic environment". According to Gerson (2004: p. 167),

"the rise of new, more diverse work and family patterns is rooted in economic and social changes that are endemic to all post-industrial societies".

Those socio-economic and environmental changes force families to adapt to changes for survival. Accordingly, the traditional perception towards women as a mother or a wife and men as the breadwinners has become an illusion (Higgins et al., 1994). Therefore, most married 
couples have become dual earners to be "economically viable" (Haddock et al., 2006: p. 207). McGovern (2009: p. 42) introduced this as "dual income workaholic consumerism". Accordingly, today, both men and women are playing similar roles (Bloemberg \& Beek, 2011).

\section{Work-family balance}

Work-family balance is a "satisfaction and good functioning at work and at home, with a minimum role of conflict" (Clark, 2000: p. 751). İndeed, work-family balance does not expect an allocation of an equal amount of time between the work and family domains except the allocation of the right amount of time between the two spheres (Malik et al., 2010; Kotawska et al., 2010). It is a wise utilisation of time between work life and family life (Erdem \& Karakose, 2008). A study on the workfamily balance of six Australian organisations has found that the inability of time management between work and family leads to absenteeism and turnover of their staff (Burgess et al., 2007). Surprisingly, in Britain, most of the employees do not want to alter their 'long hours culture' but women are eager to change their working time because of child-caring and rearing responsibilities (McGovern, 2009: p. 40). It was further found that especially women were more likely to arrange their time between work and family by giving more priority to household demands. Further, McGovern (2009) has found that $40 \%$ of women with dependent children and $55 \%$ percent of women with children less than three years of age were increasingly asking for changing hours from employers because of their household obligations. Irrespective of the job type, women allocate more time to child-caring than men (O'Laughlin \& Bischoff, 2005). Especially, full time employed women with young children experienced more work-family imbalance than fulltime employed men with young children (Milkie \& Peltola, 1999).

There is a difference in how women and men deal with work-family matters and the way they manage them. Many researchers have identified significant gender differences under the context of work-family balance. As stated by Milkie \& Peltola (1999), women are engaged in more household work than men and the cultural context expects more involvement from women to household obligations as compared to men. Surprisingly, the results of their study based on time, role harmony and tradeoff variables do not show a significant gender difference in the achievement of work-family balance. Similarly, Van der Lippe et al. (2006) argued that combination pressure is higher among women than men compared to their higher involvement with household chores than their partners. Furthermore, they stated that "the household situation contains elements which, especially for women, lead to more combination pressure". Moreover, women in the study of Van der Lippe et al. (2006) argued that paid work put them in a scarcity of time for household work. Men in many countries have admitted that "they do less than their fair share; while women declare that they do more than their fair share" (Kotowska et al., 2010: p. 1). However, this study did not represent uniformity in men's opinions regarding their 'fair share.' In the Pakistani socio-economic culture, Gomez et al. (2010) found that "women are better able to manage their work and family affairs compared to male individuals". Mostly, when men are engaged with paid employment, they are inclined to neglect their responsibilities towards the family. They justify it, using the culture and put the burden on the shoulders of their wives. Especially, females who are engaged in higher career positions are exposed to imbalance than males (Guest, 2002), since the higher positions require excessive responsibilities and workload. Importantly, those professional workers do not choose reduced work hours due to the fear of career breakdowns (Lautsch \& Scully, 2007).

\section{Nevertheless,}

"in a world, where personal relationships and job commitments are fluid and unpredictable, women and men alike must balance their commitments to others with the search for self-sufficiency" (Gerson, 2004: p. 169).

As a reason for the women's ability to balance work and family, Gomez et al. (2010: p. 51) have stated that work engagement is the only opportunity available for women, which sets them apart from family obligations. Males believe that after a long day of hectic commitments and being physically burnt-out and mentally exhausted, they find less time to get involved in family commitments, whereas women have to work hard to perform well in an organisational environment. However, "work interfering with family and family interfering with work" have "negatively impacted on organisational, family and personal outcomes" (Boyar et al., 2008: p. 216). Most of the scholars (McGovern, 2009; Lewis et al., 2003; Greenhaus et al., 2003) pointed out that people tend to give priority to their work rather than to their family and then it becomes difficult to reach a balance between these two spheres. It seems that, when individuals allocate more time for work, it creates a high level of work-family conflict and stress (Greenhaus et al., 2003). 
Barnett (1999) argues that, women's entrance to the labor force creates a number of consequences such as unbearable stress, difficulties in managing demands in work and family, etc. Even today, these traditional attitudes are remaining in the mindset of many in Asian countries. Most organisations perceived women as a burden for them and hence, women are highly vulnerable to workplace discrimination due to their dual commitment to work and family. However, work organisations have an obligation to find solutions to balance work and family life, especially for women workers. Alternative work schedules are an option to achieve work-family balance. As stated by Doble \& Supriya (2010), both men and women believe that flexible work hours help them to balance work and family. Notwithstanding, as stated by Barnett (1999), though organisations have different policies to achieve work-family balance, those are only limited to books. Moreover, he argued that asking for those benefits would undermine the ability of women to manage their work and family demands.

\section{Gender difference in work-family balance among academics}

In the discussion of work flexibility, Rafnsdottir \& Heijstra (2011) argued that "time is linked to gender" due to the pressure of family obligations that comes under the knees of academic women. According to Fothergill \& Feltey (2003: p.10), "timing is an issue in the academic career and it negatively impacts on female academics' decision on childbearing and rearing activities". Ward \& Wendel (2004) argued that when a faculty attempts to attract qualified members, they should understand the challenges that women have to face in the academic environment. However, this never-ending work is the academics' choice (Currie et al., 2000). Apparently, both males and females in academia sacrifice their personal life and invest more time and energy for their institutions. They are very interested in doing their work in order to become workaholic academics. Many scholars (Hirakata \& Daniluk, 2009; Baker, 2008) have conducted studies to find out how female academics with or without children balance their work and family life. However, very little evidence was found on the work-family balance of male university academics. According to Swanson \& Johnston (2003) "success in achieving gender equity in academia partly depends on supporting faculty's roles as parents". Female academics are highly vulnerable to work-family imbalance compared to their male counterparts because people believed that "domestic tasks are women's work, not men's" (Ward \& Wendel, 2004; Santos \& Cardoso, 2008; Armenti, 2004). O'Laughlin \& Bischoff (2005) have found that there was a similarity in work stress among male and female academics; nevertheless, family stress differs according to gender. Therefore, women are saddled with more family commitments.

Earlier, Santos \& Cardoso (2008) highlighted that most studies refer to cultural norms that family responsibilities are duties of women rather than men. These findings showed that female academics have to struggle with more barriers in their career path when compared to male academics. Using 10 academic women with children under 13 years as a sample, Hirakata \& Daniluk (2009) examined the challenges faced by academic women with young children in balancing work and family life. They found that academic women experienced a sense of vulnerability, a sense of isolation, a sense of inadequacy of achieving work-family balance, overwhelming sense of stress and pressure, and a lack of support from their organisations and members of the family. However, those female academics who occupy senior management positions in the female-dominated societies are reluctant to support their fellow academics of the same gender, in contrast to the male academics who occupy the senior management positions in the male-dominated societies (Hirakata \& Daniluk, 2009). Interestingly, everyone in the sample accepts they have positive gains from their work to family life by being role models to their children and other female employees. Nevertheless, their research findings could not be generalised due to the inadequate sample.

In male-dominated academic world, women faculty members have to schedule their work 'around the university timetable' without challenging the tenure system of the university (Gatta \& Roos, 2004: p.130). Moreover, academics do not receive any support from the university and most academics perceive "family work integration as a major problem throughout their university careers" (Gatta \& Roos, 2004). Panofsky (2003: p.105) in her study of 'Professor/Mother, The uneasy partnership', clearly stated that 'the university, an institution shaped by men for their own privilege, has a long history of excluding women as students and professors". Not surprisingly child-caring is the major issue that they have to face and most academics are struggling to be ready for childbirth "around sabbaticals and semester breaks" without blaming "university policies, procedures or way of life" (Gatta \& Roos, 2004: p. 130). "Childbearing was divorced from academic life" until women participated in the academic field in growing numbers (Panofsky, 2003: p.105). Academic women feel a 'sense of vulnerability' because of their children and they have to encounter risk in their career when they decided to get "full maternity leave" (Hirakata \& Daniluk, 2009: p. 286). Consequently, women were discouraged to enjoy leave that they are entitled to. Their 


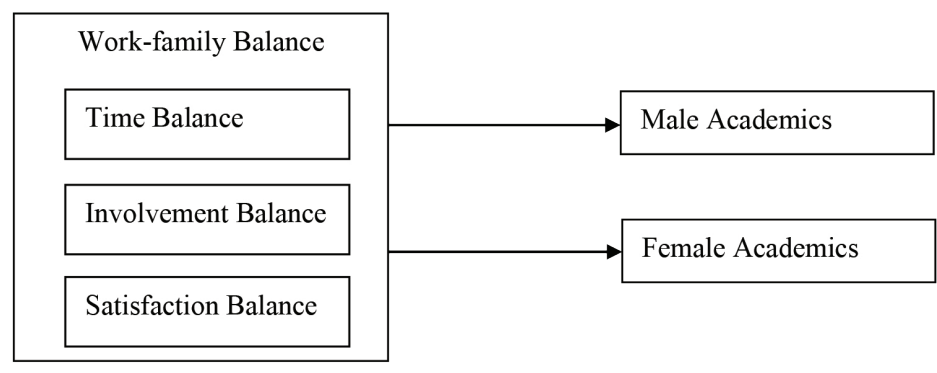

Figure1: Conceptual framework

situation is different from the situation of men who have wives at home, and women and men without children (Hirakata \& Daniluk, 2009).

Most of the members of the faculty are dual earners (Jacobs \& Winslow, 2004). Baker (2008) examined the gender differences in the family life of academics among a sample of 30 full-time male and female academics. He stated that since the 1970s there was a tendency among female graduates to join higher positions in their careers. Further, Baker (2008: p.1) found that there is a difference in the 'pattern of family formation' and most of the men are concerned about marriages and have children while their female counterparts get divorced without having children. However, male academics received support from spouses in their work (Baker, 2008). Male academics have 'personal autonomy' towards their time when compared to women academics, and they can use that time for their own interests (Rafnsdottir \& Heijstra, 2011: p.12). In that view, male academics perceive their workload as normal and not as stressful. Nevertheless, women academics complained about their stress due to lack of "childcare services and restricted geographic mobility and career opportunities" (Baker, 2008: p. 7). It showed that children are a major factor for the stress of women academics (Baker, 2008). Rafnsdottir \& Heijstra (2011) in their study pointed out that, male academics are more likely to manage their time compared to women academics in Iceland's structure and men are better able to balance their work and family life. According to Ward \& Wendel (2004: p. 234), "women faculty themselves bear significant responsibility for achieving their own sense of balance". This hectic workload negatively affects employees' intention to have a balance between work and family.

\section{Conceptualising work-family balance}

Various scholars have measured work-family balance in many different ways and among them, Grzywacs \& Carlson (2007) measured work-family balance in respect of two dimensions as work-related outcomes and familyrelated outcomes. Work-related outcomes consisted of three indicators such as job satisfaction, attitudes towards employer and job stress. Family-related outcomes were measured through family satisfaction, marital satisfaction and overall stress. According to Saltzstein et al., (2001) work-family balance was measured through job demand, job involvement, family demand, and family involvement. Greenhaus et al. (2003) have proposed a measure to assess work-family balance, using three components. These are time balance, involvement balance and satisfaction balance. According to their view, it helps to measure the work-family balance in relation to negative and positive perspectives, considering that 'level of time, involvement or satisfaction are equally high or equally low.'

According to previous studies, time balance (an equal amount of time devoted to work and family roles), involvement balance (an equal level of psychological involvement in work and family roles) and satisfaction balance (an equal level of satisfaction with work and family roles) were important in assessing work-family balance (Greenhaus et al., 2003). Accordingly, workfamily balance can be positive or negative (Greenhaus et al., 2003).

Based on previous studies, the conceptual framework given in Figure 1 was developed. The hypothesis was formulated to examine the gender difference of the workfamily balance of university academics. The reasons for the predictions are as follows. According to Milkie \& Peltola (1999), women engage in more household work compared to men and the cultural context expects more involvement from females to household obligations relative to men. Women consulted by Van der Lippe et al. (2006) argued that paid work put them in difficulty to find time for household work. Men in many countries admitted that "they do less than their fair share; while women declare that they do more than their fair share" (Kotowska et al., 2010). Noor (2006) found that women 
spend more time on family, relative to men, though they preferred more to involve with fulltime employment. Van der Lippe et al. (2006) argued that combination pressure is higher among women as compared to men due to their higher involvement with household chores when compared to their partners. Especially, women who are engaged in higher positions are exposed to more imbalances as compared to men (Guest, 2002) because higher positions increased the demands of the job and they have to work more on it. Similarly, women's job performance negatively affects their 'marital satisfaction' due to a high level of role conflict (Greenhaus et al., 1987). In the light of the above evidence, the researchers have developed the following hypothesis.

Hypothesis 1: Work-family balance is higher among men when compared to women.

\section{METHODS}

This study used a quantitative approach because it deals with theory testing and not with theory development. The population of the study was all the university academics in Sri Lanka. The academics in Management Faculties of four universities were included in the sample. According to the statistics of the University Grants Commission as of $31^{\text {st }}$ of December 2017, the Management Faculties of the University of Sri Jayewardenepura, University of Colombo, University of Kelaniya and University of Ruhuna consisted of 397 academics. Among them, 210 were female and 187 were male academics. By using the cluster sampling technique (Sekaran \& Bougie, 2010: p. 295), 196 academics were selected from the aforesaid universities as the sample. However, only 63 male academics responded to the questionnaire as compared to
133 female academics available in the relevant Faculties. Therefore, researchers selected 63 female academics randomly, since it is required to numerically equate the number of male and female academics to validate the comparison.

A structured questionnaire was designed to collect data on work-family balance of academics and it was distributed by the researchers themselves. To increase the response rate, the questionnaire distribution procedure involved follow-up contact with participants. The questionnaire used in this study is composed of two parts. The first part covered demographic factors such as gender, marital status and tenure. The second part covered the key variable, work-family balance by using the three dimensions; time balance, involvement balance and the satisfaction balance, as per the study of Greenhaus et al. (2003). The second part included questions with Likert scale, where the respondents had the freedom to select their level of agreement or disagreement, such as: Strongly Disagree, Disagree, Neither agree nor disagree, Agree, Strongly Agree; numbers assigned for each answer was 1, 2, 3, 4 and 5. Independent sample t-test was employed for the purpose of data analysis.

\section{Measurement}

In this study, the work-family balance acted as the independent variable. According to the previous researcher (Greenhaus et al., 2003), three dimensions were identified under work-family balance (Cronbach's $\alpha=0.732$ for the whole sample) as time balance, involvement balance, and satisfaction balance. Time balance was measured by using 4 items (e.g., 'When I am working, I give my complete attention to what I

Table 1: Demographic data of the sample

\begin{tabular}{lrrr}
\hline & Variable & Sum & $\%$ \\
\hline Gender & Men & 63 & 50 \\
& Women & 63 & 50 \\
Marital status & & & \\
& Married & 92 & 73 \\
& Single & 34 & 27 \\
Position & & & \\
& Professor & 3 & 2.4 \\
& Senior Lecturer Grade I & 24 & 19.0 \\
& Senior Lecturer Grade II & 29 & 23.0 \\
& Lecturer & 57 & 45.2 \\
& Probationary Lecturer & 13 & 10.3 \\
\hline
\end{tabular}


am doing') following a scheme developed by Marshall \& Barnett (1993). These 4 items were measured on a 5 point Likert scale from strongly disagree to strongly agree. Involvement balance was assessed with 4 items and 2 of them (e.g., 'Most important things which I value (recognition, admiration, etc) are happening to me when I am at my job', 'Most important things which I value (recognition, admiration, etc) are happening to me when I am with my family') was measured on a 5 point Likert scale from strongly disagree to strongly agree. Four items were used to assess the satisfaction balance and those four items (e.g., 'I am generally satisfied with the kind of work I do for my family', 'I am satisfied with the success I have achieved in my job.') were measured on a 5 point Likert scale from strongly disagree to strongly agree.

\section{RESULTS AND DISCUSSION}

Table 1 shows that the sample comprised 63 men and 63 women academics. Moreover, results reveal that 92 are married respondents while 34 are single. Thus, the majority of the respondents are married.

Table 2 and 3 show the results in relation to independent sample t-test. According to the results of the independent sample t-test for time balance, Sig. (2-Tailed) value was 0.001 . This value is less than 0.05 . Hence, there is a statistically significant difference in the mean value of time balance between male and female. According to mean values, women admitted that they were able to balance their time between work and family, as compared to men. One possible explanation for this finding may be that most working mothers/females receive support from their family members to manage their day-to-day activities. However, this finding is inconsistent with many of the previous research findings (Acker \& Armenti, 2004; Van der Lippe et al., 2006;
Bianchi et al., 2000). Acker \& Armenti (2004) have stated that the academic profession has developed around the male life course and hence, academic women have to adapt to the male life course to achieve their targets at university. Combination pressure is reportedly higher among women than men due to their higher involvement with household chores than their partners and furthermore, "the household situation contains elements which, especially for women, lead to more combination pressure" (Van der Lippe et al., 2006, p. 316).

Moreover, Sig. (2-Tailed) value of independent sample t-test for involvement balance was 0.005 . It was less than 0.05 . Therefore, there is a statistically significant difference in mean values of involvement balance between male and female. Accordingly, results showed that women were better able to balance their involvement in both work and family, as compared to men. In this male-dominated society, women academics have to shoulder household burdens with their career expectations and according to that, men reach the highest rank in their tenure more easily than women due to their lower family workload. Though, female academics have a delay in achieving tenure, they may have the ability to contribute to both work and family life. In contrast to the above research finding, Milkie \& Peltola (1999) have stated that women are engaged in more household work than men and the current cultural context expects more involvement from women in household obligations in comparison to men. When women decide to stop their work for a specific period due to their pregnancy or any other family obligation, they have to tackle many problems in achieving tenure, because they could not stop their biological clock (Hirakata \& Daniluk, 2009).

Further, Sig. (2-Tailed) value of independent sample t-test for satisfaction balance was 0.185 . It was greater than 0.05 . Therefore, there is no statistically significant

Table 2: Group statistics

\begin{tabular}{|c|c|c|c|c|}
\hline & Gender & $\mathrm{N}$ & Mean & Std. deviation \\
\hline \multirow[t]{2}{*}{ Time balance } & Men & 63 & 3.8333 & 0.41881 \\
\hline & Women & 63 & 4.1468 & 0.60348 \\
\hline \multirow{2}{*}{ Involvement balance } & Men & 63 & 3.5238 & 0.49740 \\
\hline & Women & 63 & 3.7976 & 0.57652 \\
\hline \multirow[t]{2}{*}{ Satisfaction balance } & Men & 63 & 4.0476 & 0.35881 \\
\hline & Women & 63 & 4.1508 & 0.49907 \\
\hline \multirow[t]{2}{*}{ Work-family balance } & Men & 63 & 3.8016 & 0.35178 \\
\hline & Women & 63 & 4.0317 & 0.44107 \\
\hline
\end{tabular}


Table 3: Independent sample t-test

\begin{tabular}{|c|c|c|c|c|c|c|c|c|c|c|}
\hline & & \multicolumn{2}{|c|}{$\begin{array}{c}\text { Levene's Test for } \\
\text { Equality of Variances }\end{array}$} & \multicolumn{7}{|c|}{ t-test for Equality of Means } \\
\hline & & \multirow[t]{2}{*}{$\mathrm{F}$} & \multirow[t]{2}{*}{ Sig } & \multirow[t]{2}{*}{$\mathrm{T}$} & \multirow[t]{2}{*}{ Df } & \multirow{2}{*}{$\begin{array}{l}\text { Sig } \\
\text { (Two- } \\
\text { Tailed) }\end{array}$} & \multirow{2}{*}{$\begin{array}{c}\text { Mean } \\
\text { Difference }\end{array}$} & \multirow{2}{*}{$\begin{array}{l}\text { Standard } \\
\text { error } \\
\text { difference }\end{array}$} & \multicolumn{2}{|c|}{$\begin{array}{l}95 \% \text { Confidence } \\
\text { Interval of the } \\
\text { Difference }\end{array}$} \\
\hline & & & & & & & & & Lower & Upper \\
\hline TB & $\begin{array}{l}\text { Equal } \\
\text { variances } \\
\text { assumed }\end{array}$ & 3.311 & 0.071 & -3.387 & 124 & 0.001 & -0.31349 & 0.09255 & -0.4966 & -0.1303 \\
\hline \multirow{3}{*}{ IB } & $\begin{array}{l}\text { Equal } \\
\text { variances } \\
\text { not } \\
\text { assumed }\end{array}$ & & & -3.387 & 110.477 & 0.001 & -0.31349 & 0.09255 & -0.4968 & -0.1301 \\
\hline & $\begin{array}{l}\text { Equal } \\
\text { variances } \\
\text { assumed }\end{array}$ & 0.618 & 0.433 & -2.854 & 124 & 0.005 & -0.27381 & 0.09593 & -0.4636 & -0.0839 \\
\hline & $\begin{array}{l}\text { Equal } \\
\text { variances } \\
\text { not } \\
\text { assumed }\end{array}$ & & & -2.854 & 121.39 & 0.005 & -0.27381 & 0.09593 & -0.4637 & -0.0838 \\
\hline \multirow[t]{2}{*}{ SB } & $\begin{array}{l}\text { Equal } \\
\text { variances } \\
\text { assumed }\end{array}$ & 3.502 & 0.064 & -1.332 & 124 & 0.185 & -0.10317 & 0.07744 & -0.2564 & 0.0501 \\
\hline & $\begin{array}{l}\text { Equal } \\
\text { variances } \\
\text { not } \\
\text { assumed }\end{array}$ & & & -1.332 & 112.58 & 0.185 & -0.10317 & 0.07744 & -0.2566 & 0.0502 \\
\hline \multirow[t]{2}{*}{ WFB } & $\begin{array}{l}\text { Equal } \\
\text { variances } \\
\text { assumed }\end{array}$ & 0.083 & 0.774 & -3.238 & 124 & 0.002 & -0.23016 & 0.07108 & -0.3708 & -0.0894 \\
\hline & $\begin{array}{l}\text { Equal } \\
\text { variances } \\
\text { not } \\
\text { assumed }\end{array}$ & & & -3.238 & 118.15 & 0.002 & -0.23016 & 0.07108 & -0.3709 & -0.0894 \\
\hline
\end{tabular}

( $\mathrm{TB}=$ time balance; $\mathrm{IB}=$ involvement balance; $\mathrm{SB}=$ satisfaction balance; $\mathrm{WFB}=$ work-family balance).

difference in mean values of satisfaction balance between male and female. However,women were having satisfaction in relation to work and family as compared to men. In contrast to the above finding, Andrade \& Matias (2009) stated men are more satisfied with their work while women perceive their household chores as a burden for them. Further, they have mentioned that women become satisfied when they have more workfamily facilitation at work.
Finally, Sig. (2-Tailed) value of the independent sample t-test for work-family balance was 0.002 . It was less than 0.05 . Therefore, there is a statistically significant difference in mean values of work-family balance between male and female academics. Accordingly, mean values showed that females are better able to balance their work and family in comparison to males. Similarly, Kailasapathy et al. (2014) found that work interferences with family conflict are reportedly less among females, 
compared to males in their sample. As a reason for the women's ability to balance work and family, Gomez et al. (2010) have stated that work engagement is the only opportunity available for women, which sets them apart from family obligations. Mostly when men are engaged with paid employment, they incline to neglect their responsibilities towards the family. Men in many countries admitted that "they do less than their fair share; while women declare that they do more than their fair share" (Kotowska et al., 2010: p. 1). This situation also exists in the Sri Lankan context, as women academics always have to struggle between household matters and their career. Fernando (2011) found that highly skilled Sri Lankan women have to struggle with their career advancement due to more family obligations than male counterparts. However, this study shows that, contrary to findings of previous studies in other countries, women academics have achieved more work-family balance in comparison to male academics. Especially, the social support received by women employees from their family members or paid helpers (Kailasapathy et al., 2014) may minimise their issues, leading to greater work-family balance among female university academics in Sri Lanka. Sri Lankan women usually try to balance their family and work. For women, their commitment to family responsibilities remain strong, sometimes at the risk of harming their career prospects.

\section{CONCLUSION}

Though previous researches concluded that female academics are more vulnerable to work-family conflict, the current study found that female academics are more successful than male academics in balancing their work and family life. The family support was identified as the main contributing factor for the successful work-family balance of female university academics. However, the present study indicates that work-family balance is one of the major concerns which need much attention from administrative authorities to improve the wellbeing of both male and female academics.

\section{Implications}

This research has suggested several possible managerial implications. The findings of this study indicate that women academics were able to balance work and family life more than academic men. However, to increase the level of the job performance of both male and female academics it is essential to address the issue of workfamily balance by the university administration. During the employment, administrative authorities need to increase their understanding regarding employee work roles and family roles. Through establishing an effective two-way communication they can collect more information regarding issues of academics' work and family life. Further, universities can improve academics' work life and family life by adopting supportive policies at work. Most importantly, family-friendly policies help to create a family-supportive organisational environment. Though academics enjoy academic freedom, researchers have found (Rafnsdottir \& Heijstra, 2011) it as a "doubleedged sword". Hence, while expecting an outstanding output from academics, it is quite necessary to facilitate this by developing such policies/programs even at the university level before going to the University Grants Commission level.

\section{Future research}

This research mainly focused on finding the difference between work-family balance of male and female academics. However, this study was focused only on the Mangement Faculties of four state universities. Therefore, further studies can be implemented to make a comparison between different disciplines to investigate whether the work-family balance varied among males and females based on their academic discipline. This research measured male and female academics' own judgments regarding their work-family balance. Therefore, future research can be implemented to measure both the subjective and objective balance of their time, involvement and the satisfaction to work and family. Information for this research was collected through a structured questionnaire that consisted of a set of close-ended questions. Hence, future research can be done through series of interviews with the selected sample for more in-depth investigations. Furthermore, research can be carried out by dividing the tenure track of academics according to the gender to investigate the work-family balance in relation to academics' tenure and gender.

\section{REFERENCES}

Acker, S. \& Armenti, C. (2004) Sleepless in academia, Gender and Education,16 [Online] Available from: https://www. tandfonline.com/doi/abs/10.1080/0954025032000170309 [Accessed: $16^{\text {th }}$ January 2017] pp: 3-24.

DOI: https://doi.org/10.1080/0954025032000170309

Andrade, C. \& Matias, M. (2009) Gender differences in workto-family facilitation in Portuguese employees, Exedra: Revista Cientifica, 2, pp: 161-172.

Arachchige, B. J. H. (2013) Work-life balance: does management care?, Proceedings of the HR Dialogue, 1, pp: 44-52.

Armenti, C. (2004) May babies and post-tenure babies: maternal decisions of women professors, The Review of Higher 
Education, 27(2) [Online] Available from: https://muse.jhu. edu/article/49518 [Accessed: $8^{\text {th }}$ January 2017] pp: 211-231.

DOI: https://doi.org/10.1353/rhe.2003.0046

Baker, M. (2008) The family life of academics: gendered priorities and institutional constraints, In Australian Institue of Family Studies, Annual Conference of the Australian Institute of Family Studies, Melbourne, Australia 9-11 July 2008.

Barnett, R. C. (1999) A new work-life model for the twentyfirst century, The annals of the American Academy of Political and Social Science, 562(1) [Online] Available from: https:// journals.sagepub.com/doi/abs/10.1177/000271629956200110 [Accessed: $10^{\text {th }}$ June 2017] pp: 143-158.

DOI: https://doi.org/10.1177/000271629956200110

Bianchi, S. M., Milkie, M. A., Sayer, L. C. \& Robinson, J. P. (2000) Is anyone doing the housework? Trends in the gender division of household labor, Social forces, 79(1) [Online] Available from: https://www.jstor.org/stable/2675569 [Accessed: $16^{\text {th }}$ January 2017] pp: 191-228.

DOI: https://doi.org/10.2307/2675569

Bloemberg, M. \& Beek, G. V. (2011) Gender differences in work-family conflict. Fact or fable? A comparative analysis of the gender perspective and gender ideology theory, B. Sc. dissertation, University of Utrecht, Netherlands.

Boshoff, N. \& Bosch, A. (2012) Women in South African academia: a statistical profile, South African Board for People Practices Women's Report, pp: 12-20.

Boyar, S. L., Maertz Jr, C. P., Mosely Jr, D. C. \& Carr, J. C. (2008) The impact of work/family demand on work-family conflict, Journal of Managerial Psychology, 23 [Online] Available from: https://www.emerald.com/insight/content/ doi/10.1108/02683940810861356/full/html [Accessed: $8^{\text {th }}$ January 2017] pp: 215-235.

DOI: https://doi.org/10.1108/02683940810861356

Burgess, J., Henderson, L. \& Strachan, G. (2007 September) 'I just juggle': Work and family balance in Australian organizations, Our work....our lives, In Departmnet of Industrial Relations, Griffith University, National Conference on Women and Industrial Relations: Proceedings of the $1^{\text {st }}$ Biennial Conference of the National Network of Working Women's Centres, Brisbane, Australia, 12-14 July 2006, Brisbane: Griffith University, Queensland: Queensland Working Women's Services Inc.

Clark, S. C. (2000) Work/Family Border Theory: A New Theory of Work/Family Balance, Human Relations, 53(6) [Online] Available from: https://journals.sagepub.com/doi/ abs/10.1177/0018726700536001 [Accessed: $5^{\text {th }}$ June 2017] pp: 747-770.

DOI: https://doi.org/10.1177/0018726700536001

Currie, J., Harris, P. \& Thiele, B. (2000) Sacrifices in greedy universities: are they gendered?, Journal of Gender and Education, 12 [Online] Available from: https://www. tandfonline.com/doi/abs/10.1080/713668305 [Accessed: $17^{\text {th }}$ January 2017] pp: 269-291.

DOI: https://doi.org/10.1080/713668305

Doble, N. \& Supriya, M. V. (2010) Gender differences in the perception of work-life balance, Management, 5(4) pp: 331342.

Erdem, R. \& Karakose, T. (2008) Importance of worklife balance in today's information age, Asian Journal of Information Technology, 6(12), pp: 1247-1252.

Fernando, W. D. A. (2011) Exploring the interplay between gender, social context and career: a study of professional women in Sri Lanka, PhD thesis, Loughborough University, UK.

Fothergill, L. \& Feltey, K. (2003) I've worked very hard and slept very little: Mothers on the tenure track in academia, Journal of the Association for Research on Mothering, 5(2), pp: 5-19.

Gatta, M. L. \& Roos, P. A. (2004) Balancing without a net in academia: integrating family and work lives, Equal Opportunities International, 23 [Online] Available from: https://www.emerald.com/insight/content/ doi/10.1108/02610150410787765/full/html $\quad$ Accessed: $16^{\text {th }}$ January 2017] pp: 124-142.

DOI: https://doi.org/10.1108/02610150410787765

Gerson, K. (2004) Understanding work and family through a gender lens, Journal of Community, Work and Family, 7 [Online] Available from: https://www.tandfonline.com/doi/ abs/10.1080/1366880042000245452 [Accessed: $5^{\text {th }}$ June 2017] pp: $163-178$.

DOI: https://doi.org/10.1080/1366880042000245452

Gomez, S. F., Khan, N., Malik, M. I. \& Saif, M. I. (2010) Empirically testing the relationship of social support, job satisfaction and work-family balance in Pakistani sociocultural set-up, OIDA International Journal of Sustainable Development, 2(1), pp: 51-57.

Greenhaus, J. H., Bedeian, A. G. \& Mossholder, K. W. (1987) Work experiences, job performance, and feelings of personal and family well-being, Journal of Vocational Behaviour, 31 [Online] Available from: https://www.sciencedirect.com/ science/article/abs/pii/0001879187900571 [Accessed: 26 $6^{\text {th }}$ August 2017] pp: 200-215.

DOI: https://doi.org/10.1016/0001-8791(87)90057-1

Greenhaus, J. H., Collins, K. M. \& Shaw, J. D. (2003) The relation between work-family balance and quality of life, Journal of Vocational Behavior, 63 [Online] Available from: https://www.sciencedirect.com/science/article/abs/pii/ S0001879102000428 [Accessed: $5^{\text {th }}$ June 2017] pp: 510-531.

DOI: https://doi.org/10.1016/S0001-8791(02)00042-8 
Grzywacs, J. G. \& Carlson, D. S. (2007) Conceptualizing work-family balance-Implications for practice and Research, Advances in Developing Human Resources, 9 [Online] Available from: https://journals.sagepub.com/doi/ abs/10.1177/1523422307305487 [Accessed: 10 ${ }^{\text {th }}$ June 2017] pp: 455-471.

DOI: https://doi.org/10.1177/1523422307305487

Guest, D. E. (2002) Perspectives on the study of worklife balance, Social Science Information, 41(2) [Online] Available from: https://journals.sagepub.com/doi/ abs/10.1177/0539018402041002005 [Accessed: $5^{\text {th }}$ June 2017] pp: $255-279$.

DOI: https://doi.org/10.1177/0539018402041002005

Haddock, S. A., Zimmerman, T. S., Ziemba, S. J. \& Lyness, K. P. (2006) Practices of dual-earner couples successfully balancing work and family, Journal of Family and Economic Issues, 27(2) [Online] Available from: https://link.springer. com/article/10.1007/s10834-006-9014-y [Accessed: $16^{\text {th }}$ January 2017] pp: 207-234.

DOI: https://doi.org/10.1007/s10834-006-9014-y

Higgins, C., Duxbury, L. \& Lee, C. (1994) Impact of life cycle stage and gender on the ability to balance work and family responsibilities, Journal of Family Relations, 43(2), pp: 144150.

DOI: https://doi.org/10.2307/585316

Hill, E. J., Ferris, M. \& Märtinson, V. (2003) Does it matter where you work? A comparison of how three work venues (traditional office, virtual office, and home office) influence aspects of work and personal/family life, Journal of Vocational Behavior, 63, pp: 220-241.

DOI: https://doi.org/10.1016/S0001-8791(03)00042-3

Hirakata, P. E. \& Daniluk, J. C. (2009) Swimming upstream: The experience of academic mothers of young children, Canadian Journal of Counseling and Psychotherapy, 43(4), pp: 283-294.

Jacobs, J. A. \& Winslow, S. E. (2004) Over worked faculty: Job stresses and family demands, The ANNALS of the American academy of Political and Social Science, 596(1), pp: 104-129. DOI: https://doi.org/10.1177/000271620459600105

Kailasapathy, P., Kraimer, M. L. \& Metz, I. (2014) The interactive effects of leader-member exchange, gender and spouse's gender role orientation on work interference with family conflict, The International Journal of Human Resource Management, 25(19) [Online] Available from: https://www. tandfonline.com/doi/abs/10.1080/09585192.2014.891637 [Accessed: $8^{\text {th }}$ June 2017] pp: 2681-2701.

DOI: https://doi.org/10.1080/09585192.2014.891637

Kotowska, I. E., Matysiak, A., Styrc, M., Pailhe, A., Solaz, A., Vignoli, D. \& Parenti, G. (2010) 'Family life and work', second European quality of life survey, European Foundation for the improvement of living and working conditions, Luxembourg: Office for Official Publications of the European Communities.
Lautsch, B. A. \& Scully, M. A. (2007) Restructuring time: Implications of work-hours reductions for the working class, Human relations, 60(5), pp: 719-743.

DOI: https://doi.org/10.1177/0018726707079199

Lawton, L. \& Tulkin, D. (2010) Work-family balance, family structure and family-friendly employee programs, In Population Association of America, Annual Meeting of the Population Association of America, Dallas, Texas, USA, 15 April 2010.

Lewis, S., Rapoport, R. \& Gambles, R. (2003) Reflections on the integration of paid work and the rest oflife, Journal of Managerial Psychology, 18 [Online] Available from: https://www.emerald. com/insight/content/doi/10.1108/02683940310511908/full/ html [Accessed: $8^{\text {th }}$ June 2017] pp: 824-841.

DOI: https://doi.org/10.1108/02683940310511908

Malik, M. I., Saif, M. I., Gomez, S. F., Khan, N. \& Hussain, S. (2010) Balancing work and family through social support among working women in Pakistan, African Journal of Business Management, 4(13), pp: 2864-2870.

Marshall, N. L. and Barnett, R. C. (1993) Work-family strains and gains among two earner couples, Journal of Community Psychology, 21, pp: 64-78.

DOI: https://doi.org/10.1002/15206629(199301)21:1<64::AID-JCOP2290210108>3.0.CO;2-P

Mcgovern, P. (2009) Will the economic downturn alter current work-life strategies? The debate on work-life balance is still in its infancy, Personalführung, 2, pp: 40-45.

Milkie, M. A. \& Peltola, P. (1999) Playing all the roles: Gender and the work-family balancing act, Journal of Marriage and the Family, 61, pp: 476-490.

DOI: https://doi.org/10.2307/353763

Moen, P., Robison, J. \& Dempster-McClain, D. (1995) Caregiving and women's well-being: a life course approach, Journal of Health and Social Behavior, 36(3), pp: 259-273.

DOI: https://doi.org/10.2307/2137342

Noor, N. M. (2006) Malaysian women's state of well-being: empirical validation of a conceptual model, Journal of Social Psychology, 146(1) [Online] Available from: https:// www.tandfonline.com/doi/abs/10.3200/SOCP.146.1.95-115 [Accessed: $9^{\text {th }}$ February 2017] pp: 95-115.

DOI: https://doi.org/10.3200/SOCP.146.1.95-115

O’Laughlin, E. M. \& Bischoff, L. G. (2005) Balancing parenthood and academia: work/family stress as influenced by gender and tenure status, Journal of family issues, 26(1), pp: 79-106.

DOI: https://doi.org/10.1177/0192513X04265942

Opatha, H. H. D. N. P. \& Perera, H. (2017) Determinants of Work-Family Balance: An Empirical Study of Accounting 
Professionals in Sri Lanka, Sri Lankan Journal of Human Resource Management, 7(1).

DOI: https://doi.org/10.4038/sljhrm.v7i1.5635

Panofsky, R. (2003) Professor/mother; the uneasy partnership, Journal of Association for Research on Mothering, 5, pp: 103111.

Rafnsdottir, G. L. \& Heijstra, T. M. (2011) Balancing workfamily life in academia: the power of time, Gender work and organization, 20(3), pp: 283-296.

DOI: https://doi.org/10.1111/j.1468-0432.2011.00571.x

Saltzstein, A. L., Ting, Y. \& Saltzstein, G. H. (2002) Workfamily balance and job satisfaction: The impact of familyfriendly policies on attitudes of federal government employees, Public Administration Review, 61(4) [Online] Available from: https://onlinelibrary.wiley.com/doi/abs/10.1111/00333352.00049 [Accessed: $10^{\text {th }}$ June 2017] pp: 452-467.

DOI: https://doi.org/10.1111/0033-3352.00049

Santos, G. G. \& Cabral-Cardoso, C. (2008) Work-family culture in academia: a gendered view of work-family conflict and coping strategies, Gender in Management: An International Journal, 23 [Online] Available from: https://www.emerald. com/insight/content/doi/10.1108/17542410810897553/full/ html [Accessed: 26 ${ }^{\text {th }}$ August 2017] pp: 442-457.

DOI: https://doi.org/10.1108/17542410810897553
Scott,J.W.(1986)Gender: a useful category of historical analysis, The American Historical Review, 91 [Online] Available from: https://www.jstor.org/stable/1864376? origin=crossref\&seq=1 [Accessed: $9^{\text {th }}$ February 2017 ] pp: 1053-1075.

DOI: https://doi.org/10.2307/1864376

Sekaran, U. \& Bougie, R. (2010) Research methods for business: A skill-building approach ( $5^{\text {th }}$ Ed.), Haddington: John Wiley \& Sons.

Swanson, D. H. \& Johnston, D. D. (2003) Mothering in the ivy tower; Interviews with academic mothers, Journal of Association for Research on Mothering, 5(2), pp: 63-75.

Van der Lippe, T., Jager, A. and Kops, Y. (2006) Combination pressure: the paid work-family balance of men and women in European countries, Acta Sociologica, 49(3), pp: 303-319.

DOI: https://doi.org/10.1177/0001699306067711

Ward, K. \& Wendel, L. W. (2004) Academic motherhood: managing complex roles in research universities, The Review of Higher Education, 27, pp: 233-257.

DOI: https://doi.org/10.1353/rhe.2003.0079

Wickremasinghe, M. \& Jayatilaka, W. (2006) Beyond Glass Ceilings and Brick Walls-Gender at the Workplace, Colombo: International Labor Organization and the Employers' Federation of Ceylon. 